\title{
Biblical Legends in the Folklore of the Turkic Peoples 113 in Southern Siberia
}

\section{Biblical Legends in the Folklore of the Turkic Peoples in Southern Siberia}

\author{
Nadezhda Oinotkinova \\ Siberian Branch of the Russian Academy of Sciences \\ Novosibirsk, Russia
}

\section{Abstract:}

The article deals with the ethnic specificity of biblical legends about the flood and the Tower of Babel in the folklore of the Turkic peoples of Southern Siberia (the Altai, Tuva, Khakassia and Shor). These folk legends, rooted in early Christianity, confirm the cultural and historical contacts between the peoples of Central Asia and peoples holding Christian beliefs. The subjects of the legends, associated with the biblical idea of the creation of the world and man and the flood, found their way into Siberia even before the Russians initiated the process of Christianization in the region from the seventeenth to the nineteenth centuries. This assertion is confirmed not only by the specific features of folk legends under discussion, but also by historical data on the influence of Manichaeism and Nestorianism on the culture of the Central Asian peoples, including on the Turkic peoples of Siberia. The persistence of these legends can be attributed to the fact that their plots are often adapted to local realities, concepts, myths, and events. In the construction of these narratives, use is made of national mythological terminology and conceptual systems. The saturation of the folk legends with local mythology and local beliefs in the Siberian context may be a contributing factor to their ongoing existence as a part of the folklore. The appropriation of the contents of biblical legends by the peoples of Siberia also shows the seriousness of their adoption of Christian ideas in the distant past.

Biblical legends about the flood are found in many nations, including among the Turkic peoples of Siberia (the Altai, Tuva, Khakassia, Shor), who, to a greater or lesser extent, have been 
influenced by Christianity. Legends connected with the Old and New Testament are one of the most fruitful areas for exploration of mutual influences in the folk cultures of various nations. For many years, research on Christian folklore was rare in folkloristics, but at this point, we have solid textual sources as well as significant research on East Slavic folk material. For this study, we drew on the works of O. V. Belova [2004, 2006, 2008], V. S. Kuznetsova [1997, 2008, 2009], and V. V. Napolskikh [1990].

The goal of our study is to identify the historical and ethnographic context, as well as ethnographic features of folk legends about the flood and the Tower of Babel in the folklore of the Turkic peoples of Southern Siberia and to demonstrate that they were adopted into local folklore much earlier than the $18^{\text {th }}$ and $19^{\text {th }}$ centuries, when Russian missionaries came to these lands. This analysis was based on texts from the Altai, Tuva, Khakass and Shor in the works of N. F. Katanov [1907] and V. I. Verbitsky [1893] as well as those in volumes "Tale Prose of the Altai" by N. Oinotkinova et al. [2011], "Myths, Legends and Traditions of the Tuva" by N. Alekseev et al. [2010], "Folklore of the Shor" by L. Arbachakova [2010] in the series Памятники Фольклора народов Сибири и Дальнего Востока [Monuments of Folklore of the Peoples of Siberia and the Far East] (4 plots with 9 variants of those plots). V.I. Verbitsky [1893] published only Russian versions of the texts and were provided as options in order to trace the development of certain themes and motifs. (1) We do not have the originals of those texts.

Indigenous peoples of Siberia deep in the past were animists and shamanists. Aboriginal myth-ritual folklore originated based on animistic beliefs. Great sky (Teneri) was a deity of the ancient Turks. Grandiose prayers to him were held in the days of the ancient Turkic khanate. In medieval epitaphs carved on rocks, there are direct references to the Sky: "Tengri!" They stated: "The sky is so desired," "The sky (Heaven) is my (god)—a roof to us!", "The sky bestows a divine state, the people - the Great Hagan, liberty and destiny-to every person" [Malov 1951: 62, 66, 99]. Ancient Turkic monuments also referred to Erlik, Lord of the Underworld. Erlik Khan was one of the most powerful creator gods and was revered by all Turkic peoples. He received sacrifices in the distant past and still 


\section{Biblical Legends in the Folklore of the Turkic Peoples 115 in Southern Siberia}

does today today. For this purpose, Turkic peoples choose the best horse, typically a pinto, from the herd and devoted it to Erlik; this horse was called Yyyk (Yzyh).

Scholars of history and ethnography have suggested that Christian ideas first penetrated Central Asia together with Manichaeism [Sagalaev 1984: 4; Kyzlasov 1999, 2000]. (2) In later centuries, Christianity arrived in Central Asia with a wave of Nestorianism [Tokarev 1936: 134; Sagalaev 1984: 4]. (3) S. A. Tokarev noted that Nestorianism in Central Asia was dominant in the state of the Khereids and the Naimans; it was also strong among the Genghisids and left its imprint on the religion of the Altaians. The cosmogonic myths of the Altaians, recorded by V. I. Verbitsky, show a close resemblance to biblical cosmogony and, in all likelihood, have a Nestorian origin [Tokarev 1936: 134].

Central Asia, primarily the territories of present-day Mongolia, was the object of direct missionary activities of the Nestorians from the West, since Middle Asia, Iran, and the Middle East had trade relations with Central Asia. It also might have experienced the influence of Nestorians from China. Nestorianism did not achieve complete success in Central Asia, but "by the middle of the ninth century or somewhat earlier, the Nestorian type of Christianity came into some degree of acceptance among the Kyrgyz aristocracy and, subsequently, among the wider layers of population, yet it did not drive out the local shamanic cults" [Kliashtorny 1959: 167].

The folklore of many of the present-day Central Asian peoples, most of whom do not now follow Christianity, for example, the Kazakhs, the Kirghiz, and the Bashkirs, also contains the legend about the flood, God's creation of the first people, the Tower of Babel, the end of the world, etc. The legends containing biblical stories penetrated into this vast territory at different times with different peoples as a result of cultural contacts. Folklorization of Christian ideas through oral narration of legends contributed to their wide distribution among various cultures.

The subsequent wave of Christianization of Siberian ethnic groups occurred during the Russian settlement of Siberia in the eighteenth and nineteenth centuries. In that period, through the efforts of the Altai Spiritual Mission that worked in the Altai and in 
Shoria, a significant portion of the Holy Scriptures, some Psalms, the Commandments, and prayers were translated into the Altai language.

It was not likely that the Siberian peoples adopted Russian folklore in the eighteenth and nineteenth centuries, since at that time there were almost no schools, and only a small percentage of the population could learn a foreign language. The comprehensive learning of the Russian language became only possible in the early twentieth century after the October Socialist Revolution. The appropriation of the contents of biblical legends by the peoples of Siberia provides evidence for their adoption of Christian ideas in the distant past.

The religious beliefs of the modern Altaians, Tuvinians, Khakasses, and Yakuts demonstrate syncretic elements: most of the population remains animist, while a small portion adhere to Buddhism or Orthodox Christianity. Many scholars who have studied the religion of the ethnic minorities in Siberia note that these peoples were Christianized only formally. Currently, for example, in the Altai Mountains only about $1-1.5 \%$ of the indigenous population hold to the Orthodox religion; according to the 2010 Census, there were 81,096 Altaians, 72,959 Khakasses, 12.888 Shors, 263,934 Tuvinians, and 478,085 Yakuts in the population. Orthodox traditions among Telengits of the Ulagan district of the Altai Republic have been revived in the last 20 years. For the Turkic peoples of Siberia, Orthodoxy remains a foreign culture. Very few people go to Orthodox churches in spite of the fact that they exist in many areas. Our field observations show that legends with Christian themes are told not only by baptized indigenous people, but also by animists. In their words, they heard these stories from their ancestors. Altaic narratives relating biblical plots, such as the recordings made in the end of nineteenth century, at the beginning of the twentieth century, and in the 1980s-90s would likely be classified as legends, because they retain at their core ancient biblical stories. More contemporary texts composed in the late twentieth century more resemble an abbreviated toponymic tradition; they do not retell Bible stories in any detail, but include references to biblical figures and locations, indicating a shift in the 


\section{Biblical Legends in the Folklore of the Turkic Peoples 117 in Southern Siberia}

oral tradition.

The folk legends of the Turkic people of Siberia about the flood consist of the following essential elements: Noah's preparations for the flood and his construction of the ark; confrontation with the devil, who aims to destroy the human race; the continuation of the flood for 40 days (and the death of the mammoth); the termination of the flood and the release of birds from the ark.

Adaptation within borrowed biblical legends often occurs at the level of vocabulary (e.g., character names, names of flora, place names, etc.) as wells as insertion of plot details. For example, the text "Shayyk [The Flood]" (see appendix sections 1-4), composed by the Kumandins, a northern ethnic group in the Altai, and its variants present the image of a mythical blue goat [kök teke] with iron horns, who, sensing the approaching catastrophe, ran around the earth seven times [Oinotkinova et al. 2011: 116-117, 428]. The epithet kök 'blue', may indicate the goat's origin in the element of water, thus logically associating this animal with the flood. The legend says that this creature appeared before the flood:

Шайык шыгарда, тебир мӱӱстиг кӧк теке чети кӱн, чети катап чер айландыра, мараап чат чӱгӱрчӱрдир. Чети кӱн чер силгинен. Чети кӱн кырлар кӱйген, чети кӱн ньанмыр чагтыр. Чер чарылган. Чарыктарын сары суг толгон. Чети кӱн тоол кирген, мӱндӱр барган. Чети кӱн кар тӱшкен. Ан соондо соок болгон...

[When the flood occurred, a blue goat with iron horns, bleating, in seven days ran seven times around the earth. For seven days, the earth trembled. For seven days, the mountain burned, for seven days, there was a downpour. The earth split. Cracks were filled with water. For seven days they were filled, and hail fell. For seven days, snow fell. Then it was cold...]. [Oinotkinova et al. 2011: 116]

In this text, it is clear that the appearance of the blue goat portends disaster associated with the element of water. The goat's role as a harbinger of water-related disaster is consistent with the content of 
another legend, in which people saw the goat for the second time before the ice age began.

Mythical images related to this element are comparable to the image of the red bull, a harbinger of disaster associated with the element of fire.

Altai legends about the Flood as well as the legends about the creation of the world and humans clearly manifest the idea of the dualism of light and dark principles typical for Manichaeism. The text, "Shayyk [The Flood]" says that instead of Noah and his family, seven brothers were saved in the ark; the eldest of them was Erlik (the Devil), and the youngest was Ulgen (the God). In the Old Testament the Devil is not mentioned as a character. The narrator of this text indicates the precise number of the survivors, i.e., a total of eight people. In the Bible the number of Noah's family is not written: "And Noah went in, and his sons, and his wife, and his sons' wives with him, into the ark, because of the waters of the flood" [King James Bible, Genesis 7: 7].

In the Altaic "Legend of Noah" Ulgen, or Kudai (this word has Persian (Indo-Iranian) origin), says to a righteous man named Noah that the Flood will come soon. Erlik, having learned that Noah wants to be saved from the flood and is building an Ark, tries to prevent Noah from doing this.

In this variant the devil comes to Noah's wife in the form of a man in a yellow felt coat, (Erlik's traditional way in Altaic folklore), and thus he was "imported" into the biblical story intact. The name of Noah has also been replaced by öbögön [husband], kizhi [man], and ayyldyn eezi [the owner of the yurt] [Oinotkinova et al. 2011: 126-131]. In addition, another Altai legend, "Kovcheg [Ark]" precisely specifies the number of Noah's family that boarded the ark, namely eight people: Noah, his sons, their three sons, and their wives.

Adaptation of the plots borrowed from biblical legends among the Turkic peoples of Siberia often included the introduction of myths that explain the creation of cultural artifacts or that explain the division of society into different tribal groups, clans or the system of various types of individual character. For example, when Noah's wife helped to raise the oars, she tore the clothes on her back. 


\section{Biblical Legends in the Folklore of the Turkic Peoples 119 in Southern Siberia}

Ripping her clothes is a reference to a slit in the fabric on the chegedek, the traditional coat worn by women in the Altai. This element is derived an etiological myth explaining the appearance of some Altaic peoples:

Озо-озо, озогы ӧйдӧ, Алтайда Ноой деп кижи јаткан. Јер ӱстинде агаш-таш бар ӧйдӧ, ол тушта чайык чыккан эмтир. Ноой бала-барказыла кожо јаан сал, кайык эткен. Јаан тайгага, Себи бажына, мал-аш чыгарып, анайып тынын алгандар. [Long ago, in ancient times in the Altai there was a man named Noah. When on earth has already been created by nature, it is the flood, then came the flood, it turns out.]

Ноойлор - ол ло аргаданып, арткан улус. Ол улустан ноой-майман, ноой-кыпчак, ноой-тодош — кӧп арткан улусты Ноой улузы дежер. [Noah and his children made a large raft with oars. On the big mountain, at the top of [Mount] Sebi, they raised cattle fodder, so they were saved. Noahns are the people who escaped the flood and remained there. From those people came many believed to be the people of Noah: Noah-Maiman, Noah-Kipchak, NoahTodosh]. [Oinotkinova et al. 2011: 130]

That man gave his children's children their names. Children were named for the body parts of animals. One who ate giblets (was called) Chapty, one who ate the internal fat (was) Kipchak.

In one Altaic legend Erlik sends his wife, in the guise of a mouse, to visit Noah's wife to learn what Noah has been doing. This well-known episode from biblical legend lore includes, in this case, an etiological myth that explains how the Altaic peoples learned to make arak [milk vodka] from sour milk [kefir]. The mouse teaches his wife to make arak for Noah and to give him this drink to learn Noah's secrets. Noah's wife got onto the ark only when her husband got angry and said, "Devil's wife, come into the ark!" The mouse was then able to go with her onto the ark and gnawed a hole in the bottom of the ship. A cat caught and ate the mouse [Oinotkinova et 
al. 2011: 430-431]. This episode is almost identical to an episode of the legend recorded among the Shor people (see Appendix, text "Shaiyk [The Flood]"). In addition, a similar plot occurs in East Slavic texts about the Flood, where an animal also performs the role of savior, e.g., a cat, lion, or frog [Belova 2004: 267-273].

Fragments of the confrontation with the devil are also present in the Russian translation of the legend recorded by N. F. Katanov in Kachin Khakas [1907: 417-418]. (4) According to this story, Noah's wife conspires not with the devil's wife, but with the devil himself, called Aina, an evil spirit in local folklore. However, in this case, the event is treated somewhat differently: the devil persuades Noah's husband to give Noah wine before he gets on the ark, so that the devil could sneak on as well:

Катты ебіндӓ одыр-чатса, кірпік аның ебінӓ Аіна. "Ерің каіда̄p парқан?” тідір. Піlӓ-чоқылбын, ерім каіда̄p-kаiда̄p парқан!” Аіна “чӓ”, ті̄дір, “таңда сені ерің пара̄ң, тыkтан! ті̄p, ынабассаң!” ті̄-дір”. “Сен чо̄kті̄рзаң ађа: ебімні тастап, мен каіда̄p параңмын? тіп, парчаңмын? тіп, ынабассаң!” ті̄-дір, “ођа̄-ла тың кӱстӓп-парі̄за, чо̄kті̄рзаң а5а: парар ползаң, пар позың! мен парбаспын! еді тізӓң, сені кырызар: чӓ, чо̄рт, ті̄p! еді̄ тірӓ, анаң паразаң!” Еді̄-lä ӱгрӓдіп, Аіна сык-чо̄ріб-ісчік .

[The devil says to Noah's wife, 'You do not get on until the water reaches your knee. Then the water will rise to the top edge of your underclothes. You do get on even then. Then it will reach your chest. Then your husband will say to you, 'Get on, damn it [lit. devil]!' Having said this this, he will call me also. Then we all get on the raft together!' When Noah's wife was in no hurry join her husband in the ark, he said in a heartfelt way, "Get on, damn it [lit. devil]!" It turned out that he had called the devil also]. [Katanov 1907: 303]

In a Khakassian legend about the Flood episode, the plot surrounds the death of the mammoth. V. S. Kuznetsova [2008: 5- 


\section{Biblical Legends in the Folklore of the Turkic Peoples 121 in Southern Siberia}

13] argues that the myth about the disappearance of the mammoth is one limited to local, Siberian plots in particular. In the folklore of other Siberian peoples, as this researcher has shown, this motif is presented in texts unrelated to the Flood. The texts, recorded in the Khakass and Altai regions, the mammoth's pride led to his death. In Khakass legends the cause of death of the mammoth were birds that landed on his head while he was swimming in the flood waters:

[...] Олар кеlįп, кіррчі̨ктӓр керӓпкӓ. Пыра̄i kyc, аң то̄за кįргӓн ађа. Мамыт тӓн аң кірӓгӓ ынаба̄н. Ол аң чо̄kтапчадыр: “Кырык чылды мен чӱзӥп-та̄ сыдірббын!” Паза kускун ынабачыk кірӓргӓ: “Кырыk чылды мен учуБуп-та̄ сыдіррбын!” тї-дір. Калап сыkkанда, то̄залары ak-сыkkан. “Чä, чо̄рт!” тӓн-дӓ, Аіна керӓпкӓ'к кірпарқан када. Олар

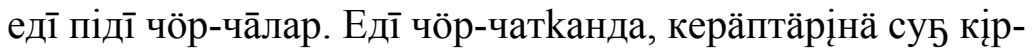
чā. Ко̄скачаk оілап-чӧріп кӱскӓ та̄б-алчыk анда, тудубалчыk. Аіна, кӱскӓ кубулуп, керӓпті тезӓ керткӓн полтыр. Анаң сықа̄ра ко̄сканың аксы пыртак пол-чаң. Кырыk чыл丂а четтірӓ чӧргӓннӓр. Чӧріпп, пі̨р-lä кӱн четпі̄н, мамыт аңның тегӓjінӓ ызықас kyckaчak одырқан. Ол мамытты суђъа кі̄рӓ пазыб-ысkан. Аң анда ӧlгӓн, ол о̄зынаңпу чердӓ чоқыл ол аң. Суђ сенгӓн; чергӓ сыkkaн kырыk чылдың пазында."

[[...] They came onto the ship. All the birds and beasts came. A beast called Mammoth did not want to get into the ship. It said: "I can swim forty days, can float, and not be on the ship!" Raven also did not want to enter into the ark: "Forty days I can fly!" - he said. When the deluge came, everything swam. When [husband] said, "Well, hell," then the devil came onto the ship with them. They sail this way and that. When they therefore were sailing, the ship began to leak. A pussy cat, who was running around, found a mouse and caught it. It turned out that the devil had turned into a mouse and gnawed through the ship. So, the cat's mouth is considered to be unclean. Been there are 40 days of age. While they were swimming, just one day into the flood, a 
bird, a titmouse, landed on top of the mammoth's head, and the mammoth drowned immediately. The beast died there, and since then it does not exist on this earth. The water subsided, and after 40 days they went to the ground]. [Katanov 1907: 303-304]

In this text narrator mistakenly used the 40 years instead of 40 days.

The number of the texts about a mammoth differs. The modern text only touches on the story of the Flood and the mammoth:

Пурунда чир ӱстӱнде уғаа улуғ потоп полыптыр. Ол суғ нинче пар чир ӱстӱн тооза чайылтыр. Хырых кӱн кӧдірілген ол чоғар. Чон корабль иттір. Ол корабльға нинче пар кізі, аң-хус сыыптыр. Ол корабльға мамин тіп аң на одырбиндыр. Ол аң: “Суғ ӱстӱне позым сығам,” тіптір. Іди сыхчатханда, нинче пар хус мӱӱзіне одырыбыстыр. Аның аарына сыдап полбин, ол аң суғ алтына кір партыр. Амғы тағлар, кӧллер, суғлар ол потоп соонаң полыптыр. Тағлар хумнаң полған, иміс. Мамин аң уғаа улуғ аң полтыр. Ам даа тидірлер: ол хайдағ-да кӧлнің тӱбінде чадыр. Ол аң хайдағ, хищнай ба, чох па полған, пілбинчадырбын.

[For a long time on the ground was huge flood, it turns out. This water covered the entire earth. Forty days later, it [the ark] climbed to the top. People built the ship. On this ship as there are people, animals, birds, [all] fit, it appears. Only the animal called Mammoth did not get on the ship. This beast said he would get out of the water himself. When he so chose, all the birds took turns sitting on his horns. Unable to bear this weight, this beast sank into the water, it turns out. Today's mountains, lakes, rivers came about after that flood, it turns out. The mountains were as if made of sand. The mammoth beast was a huge beast, it turns out. And now, they say, he's lying at the bottom of some lake. What kind of beast it was, predatory or not, I don't know. [Mindibekova et. al. 2016: 80] 


\section{Biblical Legends in the Folklore of the Turkic Peoples 123 in Southern Siberia}

However, the Altaic text contains another reason for the death of the mammoth: It sinks in water, because he hoped to rely on his strength:

Кӧп чактар мынан озо, јердин ӱстинде чайык чыккан эмтир. Ол тужунда кижи коркушту јаан сал эткен. Јердин ӱстиндеги бастыра тындуларды бир эжерден алып, салына отургузып алала, талайла кайкаладып јӱрген. Ол онойдо бастыра тындуларды ӧлӱмнен аргадаган. Је ол андардын эн јаан кааны, јаан деген ан, салга отурбаган, мойноп айткан: “Мен сен јоктон до бойым чыдажып јӱрерим. Мен бастыра андардын кааны». Ол тӧртӧн кӱнге талайла эжинип јӱрген. Онон чыдашпай, талайдӧӧн чӧнӧ берген”.

[Many centuries ago, there was a flood on the earth. At that time one man made a very big raft. And he took one pair of all the animals of the earth and put them on his raft and began to sail the sea. He saved all the animals from death. But the biggest Khan these beasts, the beast called d'aan, did not get on the raft. He refused and said, "I am without you he will survive. I am Khan all the animals". He sailed for forty days by the sea. Then, unable to bear it, he sank into the sea]. [Oinotkinova et al. 2011: 118]

In some Siberian texts, the Flood story has been contaminated with legends about the creation of the Earth. O. V. Belova believes that this practice is characteristic of several "Bible" legends [Belova 2006: 273]. The creation of the world and the Flood share the common concept that the world after the flood was created nearly from scratch:

In that day will I raise up the tabernacle of David that is fallen, and close up the breaches thereof; and I will raise up his ruins, and I will build it as in the days of old:

That they may possess the remnant of Edom, and of all the heathen, which are called by my name, saith the LORD that 
doeth this. [King James Bible, Amos 9:11-12]

This idea, for example, occurs at the end of a Shor legend:

Анаң сал шаптырпартыр эңне мӧзӱк таға Арарат теп, таға. Анаң аң-куштар по черге кадак чайалғаннар...[Then the raft washed up on the highest mountain Ararat, Ararat Mountain. Then the beasts and the birds began to be created again on this land...]. [Arbachakova 2010: 332]

In the Altaic text "The Flood" the story of the flood combines with legends borrowed from Buddhist folkloric tradition that feature a competition for supremacy in the government of the world between its creators. According to this legend, humans were created after the flood. The text notes seven brothers knew it would flood; the older brother was named Erlik, and the youngest was Ulgen:

Ӱлген дезе кижи чайап эттир. Ол дезе, кӧк чакайакты алалып, алтын айакка салалып, кижи чайап ийдир. Улуг кардашы, Эрлик, аны артык кӧрип, чарым чакайаны оорлап алтыр, Ӱлген шылап, кижи чайап ийдир....[Ulgen also created man. Then he took the blue flower, putting it in a golden cup, and created a person. The elder brother, Erlik, envied him, robbed him of half of the flower and like Ulgen, made a person]. [Oinotkinova et al. 2011: 116]

This legend also describes in detail the episode in which birds were released from the ark in order to learn about the lowering of the water level:

Карташтар кереб чазап алтырлар. Ол керебге чердин сыртында чугы бар, пеес-куш, куртан, андардан - пир тӧйден кожо аланар. Ӱлген дезе, шайык пожоды ба, деп тааканы керебтен пожот ийдир. Така дезе, соокка тогып калган. Ан сонда касты божоттыр. Кас дезе сугле ыгып, ойдо ньанмынсан. Ӱчӱнче катап Ӱлген кускунды ийдир. Кускун база ойдо келбеен, ӧлӱмнин эдини очип чӱрдир. [[Before the flood] the brothers built the ark. This ark held 


\section{Biblical Legends in the Folklore of the Turkic Peoples 125 in Southern Siberia}

everything on earth: birds, insects, animals, they took one pair of each. To check whether the flood was over, Ulgan released a chicken from the ark. The chicken froze in the cold. After this (Ulgen) released a goose. The goose just floated on the water and did not return. The third time Ulgen sent a raven. The raven also did not return, but flew off to hunt meat... ]. [Oinotkinova et al. 2011: 116-117]

The text omits the episode of the dove that flew back into the ark with an olive branch in its beak. This text hints, in addition, to a secondary plot connected to the main plot about the creation of the first humans and the dog, which God created so that it could guard the humans while he was in search of a soul for them. Erlik, supplanting the god Ulgen, breathes his soul into the prone bodies of the humans. The emergence of this myth about the first man and the dog in this story, a motif widespread in the world's folklore, supports our claim that these legends had existed among the peoples of Siberia for a prolonged period.

This myth exists in Eurasia and North America. Since this myth is also found in American Indians, it suggests that it existed in Eurasia prior to the Indian migration to America. Iu. E. Berezkin thinks that the myth of Siberian plunger existed since the Paleolithic era. Otherwise he would not have been brought to North America [Berezkin 2012: 151].

Iu. E. Berezkin concludes that there are several basic variants about the creation of humans in world folklore. According to the myth about the creation of humans recorded from the peoples of Eastern Europe and Siberia, the Creator set a dog to guard the inert human figures he had made. However, God's antagonist outwitted the watchman and enlivened them himself. In variants from Eastern Europe and Siberia, the dog did not cope with the task God had set, while, in southern of Eurasia, it was able to defend their inert bodies [Berezkin 2012: 147]. In the myths recorded in India, namely from the Munda peoples, Darada of Hindu Kush and Abkhazians, the dog defended a man from a horse that had tried to kill him. In the myth written down in India, God makes male and female figures of clay and leaves them to dry. One or two, often winged, horses break the 
figures. The Creator creates a dog or two dogs that banish the attacking horses. The horse was punished: it was deprived of wings, and the Creator gives it away to serve man [Berezkin 2012: 146]. In the Mongolian (Oirot) version, a cow, not a horse, attempts to destroy the figures [Berezkin 2012: 144].

The biblical legend of the deluge, published in V. I. Verbitsky's book Altai Foreigners [1893], has undergone significant changes due to the peculiar interpretation of important plot episodes on the basis of various facts from the history of Altai, in particular when they were under the influence of the Oyrot culture and Lamaism (Buddhism). In this legend the main character's name is not Noah, but Nam (Lama 'a Buddhist priest'). The names of his three sons are Soozun-Uul, Sar-Uul (lit. 'Yellow-son') Balyksa (lit. 'Fisherman'). The etymology of the name Soozun-Uul is unknown; we can only posit that it is possibly arose from two Altaic words: suu [water, river] with the possessive affix nun and $u u l$ [fellow, son]. It might also be related to the Mongol word susug [respected, honored, religious] [Cheremishov 1937: 309]. One consistent element of this biblical legend is narration about the origin of various ethnicities on the Earth. According to the Altaic legend, the peoples who practice paganism and shamanism emerged from Nam's son Balyksa [the biblical Ham - author's note]. His father cursed him because, when he (Nam) fell ill, Balyksa called on the services of a shaman. Nam's two other sons, Soozun-Uul and Sar Uul, were blessed by God, so that wiser peoples came from them [Verbitsky 1893: 127]. The text details episodes on Noah's preparation for the flood, the construction of the ark, and the end of flood. Ulgen tells Nam to build a raft of sandalwood. To check whether the flood had ended, Nama releases a crow, crow and magpie and finally a dove. The dove came back with a birch branch [Verbitsky 1893: 125-126]. In the Bible, the dove brought an olive leaf:

And it came to pass at the end of forty days, that Noah opened the window of the ark which he had made: And he sent forth a raven, which went forth to and fro, until the waters were dried up from off the earth. Also he sent forth a dove from him, to see if the waters were abated from off the 


\section{Biblical Legends in the Folklore of the Turkic Peoples 127 in Southern Siberia}

face of the ground; But the dove found no rest for the sole of her foot, and she returned unto him into the ark, for the waters were on the face of the whole earth: then he put forth his hand, and took her, and pulled her in unto him into the ark. And he stayed yet other seven days; and again he sent forth the dove out of the ark; And the dove came in to him in the evening; and, lo, in her mouth was an olive leaf pluckt off: so Noah knew that the waters were abated from off the earth. [King James Bible, Genesis 8: 6-11]

The Altaic and Tuvan versions relate that shamans came from the accursed son of Nama (Noah), Balyksa (Ham). Nama's son Balyksa does not receive a blessing from his father for turning to the services of a shaman:

После потопа Балыкса захворалъ и призвалъ къ себе человека, по имени Тянгару, заставивъ его камлать. Обоихъ ихъ Эрликъ научилъ: одного призвать кама, а другого - камлать. Тогда Ульгэнь сказаль Балыксе: “ты будь слуга Эрлику, потому что ты не мне приносишь жертву, и после смерти ты пойдешь къ Эрлику.” Тянгара сказалъ въ ответь Ульгэню: “пожалуй, я и тебе такимъже образомъ буду приносить жертву, какъ Эрлику.” Ульгэнь сказал ему: “отныне будетъ имя твое Кам. Кто будет подражать тебе, тоть не будеть иметь богатства на земле.” Других двухъ сыновей Намы, Соозун-уула и Сар-уула, Ульгэн благословиль и сказалъ: «оть вась произойдеть народъ благоразумный, книжники и пророки, ари и ханы, и Созун-уула я возьму къ себе на небо!"

[After the flood Balyksa fell ill and summoned a man named Tyangar and asked him to sing and perform shamanic rituals. Both had been taught by Erlik: one to call a shaman, and the other to sing and perform shamanic rituals. Then Ulgen said to Balyksa, "Be thou Erlik's servant because you do not offer sacrifices to me, and after death you will go to Erlik." 
Tyangara said in response to Ulgen, "I think, that I will make the same sacrifices to you as to Erlik". Ulgen said to him: "From now on your name will be Kam. He who will imitate you will not have the wealth on earth". ... Nama's two other sons, Soozun-Uul and Saruula, Ulgen blessed and said to them, 'You become wise people, scribes and prophets, kings and khans, and Soozun-Uul I'll take up to me in the sky'. [Verbitsky 1893: 126-127]

This negative character expressed the idea of condemning the shamans, the worshippers of the pagan deities. This erroneous interpretation appeared on the basis of homonymy of two words: the Hebrew name 'Ham' means 'hot' (according to the Haggadah, the rabbinic literature concerning the Talmud, the sons of Ham inhabit tropical countries and have a passionate character) [King James Bible, Genesis 9: 20-27], while the Turkic word $\mathrm{kham} / \mathrm{kam}$ means shaman. The name Tyangar recalls the name of the legendary hero Djangar from the epic Oirot. In this story, he appears to the readers as a shaman, a person without credibility. According to the biblical story, Noah cursed his son Ham because he ridiculed him when he was drinking wine and lying naked, while the two other sons of Noah turned away without looking at the nakedness of his father and respectfully covered him:

And Noah began to be an husbandman, and he planted a vineyard: And he drank of the wine, and was drunken; and he was uncovered within his tent. And Ham, the father of Canaan, saw the nakedness of his father, and told his two brethren without. And Shem and Japheth took a garment, and laid it upon both their shoulders, and went backward, and covered the nakedness of their father; and their faces were backward, and they saw not their father's nakedness. And Noah awoke from his wine, and knew what his younger son had done unto him. And he said, Cursed be Canaan; a servant of servants shall he be unto his brethren. And he said, Blessed be the LORD God of Shem; and Canaan shall be his servant. God shall enlarge Japheth, and he shall dwell in the 


\section{Biblical Legends in the Folklore of the Turkic Peoples 129 in Southern Siberia}

tents of Shem; and Canaan shall be his servant." [King James Bible, Genesis 9: 20-27]

In both cases, the sons defy social prescriptions appropriate to their respective cultures about respect for the father. The legend idealizes the image of Kaldan Khan:

Обратившись къ Саруулу, Ульгэнь продолжалъ: «я пошлю вамъ царя съ неба. Онъ будетъ царь царей, сила его будетъ велика, никакой богатырь его не одолеетъ, имя ему будетъ Калдан-каан. Онъ не будетъ воевать против царей. Все народы безъ войны ему покорятся.

[Turning to Saruulu, Ulgen continued, 'I will send to you the king of the sky. He is the king of kings, the force of his will be great, no hero will be able to overcome him, his name will Kaldan Khan. He will not fight against emperors. All nations will bow to him without war.']. [Verbitsky 1893: 127]

In fact, Galdan (Kaldan), who took the title of Khan in 1677 , became the absolute ruler of all Oirats Dzhungaria.

This text notes that after the flood Namu (Noah), out of gratitude and respect, was called Yayachi (lit. Creator). V. I. Verbitsky remarks that:

to this day Biisk and Kuznetsk foreigners annually, primarily in the spring, sacrifice a white sheep on a high mountain to Nama, under the name of Yaik Khan, (lit. 'Khan of the Flood'). They also call on Yaik Khan if the livestock are not thriving, because foreigners believe that their deceased relatives lead the cattle away with them to the house of the dead, from whence Yaik Khan, upon sacrificing to him, takes and forces them [the livestock] out with a flood. [Verbitsky, 1893: 126]

This text thus also explains the practice of ritual sacrifice by shamans.

According to the Altaic version, the mountains were created out FOLKLORICA 2016, Vol. XX 
of the people's fear that there would be another Flood:

По отшествіи Яячі на небо, выросъ лесъ на обращенныхъ къ северу скатахъ горъ - арга; народ размножился и наполниль землю; все говорили, впрочемъ, однимъ языкомъ. Люди, боясь потопа, вздумали сделать гору. Богу это было непріятно. Онъ посылаеть сильныя бури, такъ что и людей и камни сбрасывало сверху горы.

[Upon the departure of Yayachi ['Creator god' - author's note] to the sky, a forest grew up on the north-facing slopes of the mountains [arga]; people multiplied and filled the earth; everyone spoke, by the way, one language. People, fearing a flood, built a mountain (not a tower!). God was displeased. He sent a furious storm, so that the people and the stones were flung from the top of the mountain]. [Verbitsky 1893: 127]

In this case, the events take place in the forested mountains, while the biblical events took place in a sandy valley. The narrator, instead of the word "tower", used the word "mountain"; apparently he either did not have a lexeme to match the former or the highest items in his environment were the mountains, so that they became part of the legend. This episode contrasts to the episode in the Bible. The descendants of Noah (the tribe of Ham) constructed the tower out of fear of displacement and subjugation to slavery. They began to build a big city along with a high tower, which could serve as the center of all the tribes, and, at the same time, a sign of their equality [King James Bible, Genesis 11: 1-9].

Interestingly, the shamanic character named Tyanar (Dzhangar/Junggar), who serves as an anti-hero in this text, is the mediator between God and the people. He asks them to stop construction of the mountain. The people do not listen to him, so that Tyanar left them. Then God commanded them, saying, "You did not listen to me and Tyanar, whom I sent to you, so that you would speak different languages" [Verbitsky 1893: 127]. The appearance of the name of Tyanar to some extent demonstrates 


\section{Biblical Legends in the Folklore of the Turkic Peoples 131 in Southern Siberia}

respect for the ruler who abandoned his subjects. The recording and publication of the legend undoubtedly had the purpose of passing on the didactic lesson of obedience to the ministers of the Church as well as to condemn shamans.

In the Altaic and Tuvan versions of the biblical legend of the Flood, the events take place in the Sayano-Altai range, up in the mountains "In a particular Altai valley there lived a husband and wife with their children. The husband was hardworking, intelligent, and wise, he could do anything" [Oinotkinova et al. 2011: 126-127]. Other texts are also bound to a particular site, in particular to a certain mountain, "The remains of the raft-ark are on Mount T'al Menku, so older people said" [Oinotkinova et al. 2011: 430-431]; "At the top of the mountain Manchurek at the very high top, in a place called Erinnig-Oi, young people who lived there, a man and a woman, built an iron raft" [Alekseev et al. 2010: 47].

The motif of the flood served as the theme for the generation of various toponymic legends. Many such texts have been recorded in several areas of the Altai Mountains, which mention mountains where people allegedly were saved from the flood and, on the tops of some of these mountains, people still find remnants of the ark [Shinzhin \& Iamaeva 1994: 367]. Thus, in the Ulagansky District of the Altai Republic, where the traditions of Orthodoxy have been revived in recent decades, we recorded legends about the flood and the Mount of D'eti-Kyol'. Here is one variant told by the Christian believer Telengit T. I. Tokoekov:

Чайык болтонын билген на. Сал эткен дийт. Бастыра тынар тындудан экиден јууган, куштан-эштен, тынду немеден, бир иркек, бир тижи, јууйла, салга салала барган. Јети-Кӧлгӧ једеле, ондо бажында карантык јерге аргаданган на. Јети-Кӧл база ла Јазулуда. Ойндо анан байа чайык токтоордо, кандый куш ийеерен эди? Јер бар ба деп бар кӧрзин деп. Ол куш јалбырак тиштенеле келген.

[[Noah] knew that there would be a flood. He made a raft, people say. He gathered two of each kind of animal, one 
female and one male of all birds and the rest of the animals, and having placed them on the raft, he launched it. They saved themselves on dry land climbing the D'eti-Kyol' to their peaks. The area called D'eti-Kyol' is also on the high ground of Yazula. When the flood ended, what was the bird that was released? In order to fly and see whether there was land. That bird came back with a leaf in its beak].

[Oinotkinova et al. 2011: 132]

As we see, transformation of the legends occurs not only in terms of the time of the events, but also in terms of space, incorporating local historical events and geographical sites.

Adaptation of the legend plot to local folklore, myths, images and concepts promoted the assimilation of foreign culture, but nevertheless highlight local elements. Thus we conclude only those with a knowledge of archaic local myth would have adopted this material, a fact suggestive of the contention that these legends came to the Siberian peoples in the distant past. We hypothesize that biblical legends about the Flood and the Tower of Babel entered the folk tradition of Turkic peoples of Siberia as a result of their adaptation to local cultural and historical, ethnographic, mythological details and concepts. In constructing a story, narrators rely on national mythological terminology and figurative conceptual systems, e.g., as is clear from the example of the element of water symbolically embodied in the form of blue goat, a being associated with water in native mythology. Some texts do not even preserve the names of the main characters (Noah and his sons), but use instead nick-names or the names of historical figures known to listeners. As a result of to their prolonged existence in the oral tradition, these legends have undergone some transformations in the Siberian environment, as we have seen.

On the basis of these data, it appears that Old Testament legends about the creation of the world and man and about the flood, which consolidate Christian values designed to deter people from sin and warn them about the Last Judgment, entered the culture of the peoples of Siberia as a result of centuries of contact with the peoples who came to Central Asia spreading the ideas of Manichaeism and 


\section{Biblical Legends in the Folklore of the Turkic Peoples 133 in Southern Siberia}

Nestorianism. We therefore can conclude that certain Christian concepts had entered the culture of the Central Asian peoples long before the process of Christianization by the Russian settlers began in the region.

\section{ACKNOWLEDGEMENT}

The author would like to thank Dr. Jeanmarie RouhierWilloughby, Professor in the Modern and Classical Languages, Literatures and Cultures department at University of Kentucky for her help with the translation of this article.

\section{NOTES}

1 Verbitsky [1893: 127] cites in Russian another biblical legend, "On the Tower of Babel" that is related to the Flood cycle we have been examining. V. I. Verbitsky was a missionary, his role in spreading the ideas of Christianity, and there is the legend itself.

2 Manichaeism was a religious and philosophical doctrine originating in the third century A.D. in the Middle East. From the third to the eleventh centuries it spread from Northern Africa to China. Manichaeism found a fertile ground in Middle and Central Asia and in the eighth-ninth centuries became the state religion of the Uighurs. The founder of Manichaeism, the Persian Mani (216between 274 and 277), a native of Babylon, considered Zoroaster, Buddha, and Christ to be his forerunners. Manichaeism arose among the followers of Zoroastrianism and adopted the doctrine of the good and evil principles underlying the world from Zoroastrianism. On the basis of the Iranian Zoroastrianism, Mani combined some elements of Christianity, Buddhism, and the ancient Babylonian religion [Toporov 1988: 103-105]. Since the Iranians were the disseminators of Manichaeism, they carried the ideas of Zoroastrianism along with the ideas of Christianity, Buddhism, and the ancient Babylonian religion, As is well known, Zoroastrians were fire worshippers. The cult of worshipping fire is particularly clearly expressed in the folklore and rituals of the Altaians.

3 "Nestorianism, religious movement in Christianity, which arose in the Byzantine Empire in the 5th century. Founder of 
Nestorius, Patriarch of Constantinople in 428-31 [before a priest in Antioch (Syria). The Nestorians, retains elements of antique rationalism, the subject of criticism was the Christian mystical concept of "man-god')" [Kazhdan 1974: 522-523].

[НЕСТОРИАНСТВО - религиозное течение в христианстве, возникшее в Византии в 5 веке. Основатель Несторий, патриарх Константинополя в 428-31 [до этого был священником в Антиохии (Сирия). В Несторианстве, сохранявшем элементы античного рационализма, предметом критики являлось мистическое христианское понятие «богочеловека»)]

4 Kachin Khakases are one of the Turkic dialect groups in the part of Khakasia.

\section{BIBLIOGRAPHY}

Alekseev, Nikolai, Kuular, Dorzhu, Samdan, Zoia, Yusha, Zhanna. 2010. Алексеев, Николай, et. al. Мифы, легенды и предания тувиниев [Myths, Legends and Traditions of the Tuva]. Edited by В. В. Илларионов. Novosibirsk: Nauka.

Arbachakova, Liubov H. 2010. Арбачакова, Любовь Н. Фольклор шориев [Folklore of the Shor]. Edited by Е. Н. Кузьмина. Новосибирск: Наука.

Berezkin, Yurii. 2012. Березкин, Юрий. “Сибирскоюжноазиатские фольклорные параллели и мифология Евразийской степи" [Siberian-South Asian folkloric parallels and mythology of the Eurasian steppe], в Археология, этнография и антропология Евразии. №4 (52): 144-153.

Belova, Olga V. 2004. Белова, Олга В. Народная Библия [The Folk Bible]. Москва: Индрик.

Belova, Olga V. 2006. Белова, Олга В. “Славянские библейские легенды: от книжного источника к фольклорному нарративу" [Slavic Biblical Legends: From Source Book to Folkloric Narrative], в Первый Всероссийский конгресс фольклористов: Сборник докладов edition II: 271-289.

Belova, Olga V. and Petrukhin, Vladimir. 2008. Белова, Олга В. и Петрухин, Владимир. Фольклор и Книжность: Миф и 
Исторические Реалии [Folklore and Literacy: The Myth and Historical Realities]. Москва: Наука.

Cheremisov, K. and Rumiantsev, G. 1937. Черемисов, К. М.,

Румянцев, Г. Н. Монгольско-русский словарь [Mongolian-

Russian Dictionary]. Москва: Издание Лениннградского Восточного Института.

Katanov, Nikolai F. 1907. Катанов, Николай Ф. Образиьь народной литературы тюркскихь племень, изданные $B$. Радловым. Часть IX: Наречия Урянхайчев (Сойотов), Абаканских Татар и Карагасов. Тексты, собранные и переведенные Н. Ф. Катановым [Samples of Turkic Tribal Folk Literature, issued W. Radloff. Volume 9: Dialects of the Uryankhays (Soyats), Abakan Tatars and Karagas. The texts collected and translated N.F. Katanov]. С. Петербургь.

Kazhdan, А. Р. 1974. Каждан, А. П. "Несторинаство" [Nestorianism], в Большая советская эничиклопедия. Edited by A.M. Prohorov. Vol. 17, pp. 522-523.

The Holy Bible: Containing the Old and New Testaments. Cambridge: Cambridge University Press, 1995. Print.

Kliashtornyi, Sergei G. 1959. Кляшторный, Сергей. “Историкокультурное Значение Суджинской Надписи" [HistoricoCultural Significance of Sudzhinsky Inscriptions], Проблемы востоковедения 5: 162-169.

Kyzlasov, Leonid. 2000. Кызласов, Леонид. “Северное Манихейство и его Роль в Культурном Развитии Народов Сибири и Центральной Азии" [Northern Manichaeism and Its Role in the Cultural Development of the Peoples of Siberia and Central Asia], Древности Алтая 5. Cited by http://elib.gasu.ru/da/archive/2000/05/10.html. (consulted December 25, 2015).

Kyzlasov, Leonid. 1999. Кызласов, Леонид. “Манихейский Храм в Котловине Сорга (Республика Хакасия)" [Manichaean Temples in the Sorghum Valley (Republic of Khakassia)], Российская Археология 2: 181-206.

Kuznetsova, Vera. 1997. Кузнецова, Вера. Дуалистические Легенды о Сотворении Мира в Восточнославянской Фольклорной Традиции [Dualistic Legends of Creation in Folk 
Traditions of the Eastern Slavs]. Новосибирск: Сибирского

Отделения Российской Академии наук.

Kuznetsova, Vera. 2008. Кузнецова, Вера. "Рябчик и Мамонт в

Легендах Русской Фольклорной 'Библии"' [Grouse and

Mammoth Russian in Legends of the Folk "Bible"], Сибирский Филологический Журнал 3: 5-13.

Kuznetsova, Vera. 2009. Кузнецова, Bera. “Фольклорные Версии Легенд о Библейских Событиях и Персонажах: Источники и Механизмы Формирования" [Folklore Version of the Legend About Biblical Events and Characters: the Sources and Mechanisms of Formation], Сибирский Филологический Журнал 4: 5-13.

Malov, Serdey. 1951. Малов, Сергей. Памятники древнетюркской письменности [The Monuments of Ancient Turkic Writing: Texts and Studies]. Москва -Ленинград: Издво АH CCCP.

Mindibekova, Valentina, Sychenko, Galina. 2016. Миндибекова, Валентина, Сыченко, Галина. Несказочная проза хакасов [Tale Prose of the Khakas]. Новосибирск: Наука. (Памятники фольклора народов Сибири и Дальнего Востока; Т.34).

Napolskikh, Vladimir. 1990. Напольских, Владимир. "Миф о Возникновении Земли в Приуральской Космогонии: Реконструкция, Параллели, Эволюция" [Myth About the Origin of Land in the Ural Cosmogony: Reconstruction, Parallel Evolution], Советская Этнография 1: 65-74.

Oinotkinova, Nadezhda, Shizhin, Ivan, Iamaeva, Elizaveta, Yadanova, Kuzelesh. 2011. Ойноткинова, Надежда, и др.

Несказочная проза алтайщев [Tale Prose of the Altai]. Новосибирск: Наука. (Памятники фольклора народов Сибири и Дальнего Востока; Т. 30).

Sagalaev, Andrei. 1984. Сагалаев, Андрей. Мифология и верования Алтайцев: Центрально-азиатские Влияния [Mythology and Beliefs of the Altaians: the Central Asian's Influence]. Новосибирск: Наука Сибирское Отд-ние.

Shinzhin, Ivan and Iamaeva, Elizaveta. 1994. Шинжин, Иван и Ямаева, Елизавета. Алтай кеп-куучындар [Altai Legends.] Горно-Алтайск: Ак Чечек. 


\section{Biblical Legends in the Folklore of the Turkic Peoples 137 in Southern Siberia}

Tokarev, S. А. 1936. Токарев, С. А. Докапиталистические пережитки в Ойротии [Pre-Capitalist Relics in Oirot].

Ленинград: Социально-экономическое издательство.

Toporov, Vladimir N. 1988. Топоров, Владимир. "Мани" [Mani]

в Muфы народов мира. Edited by S. A. Tokarev. Vol. 2, pp. 103-105.

Verbitsky, Vladimir I. 1893. Вербицкий, Владимир. Алтайские Инородизь [Altai Foreigners]. Edited by A.A. Ivanovsky.

Moskva: Этнографическим Отделом Императорскаго Общества Любителей Естествознания, Антропологии и Этнографии, состоящаго при Московском Университете.

\section{APPENDIX}

Shayyk [The Flood]. Published: Oinotkinova, et. al. 2011: 116119. Recorded by F.A. Satlaev in 1984, at p. Top-Pyankova Choya District of Republic Altai, F.A. Popyeva 1916 born, to a Kuzen tribe. Translation F.A. Satlaev, and refined by N.R. Oinotkinova. Text in Kumandin's dialect.

1 Шайык шыгарда, тебир мӱӱстиг кӧк теке чети кӱн, чети катап чер айландыра, мараап чат чӱгӱрчӱрдир. Чети кӱн чер силгинен. Чети кӱн кырлар кӱйген, чети кӱн ньанмыр чагтыр. Чер чарылган. Чарыктарынсары суг толгон. Чети кӱн тоол кирген, мӱндӱр барган. Чети кӱн кар тӱшкен. Ан соондо соок болгон. Шайык шыгар деп, четти карындаш уннанар. Анар арыг кижилер болганар. Улуг карындашынын ады эрлик болтыр, ан кичийинин ады Ӱлген болтыр, кудай сӧӧктиг, номчы кижи. Карташтар кереб чазап алтырлар. Ол керебге чердин сыртында чугы бар, пеес-куш, куртан, андардан - пир тӧйден кожо аланар. Ӱлген дезе, шайык пожоды ба, деп тааканы керебтен пожот ийдир.

[When the flood occurred, a bleating blue goat with iron horns ran seven times around the Earth for seven days. For seven days the earth shook. For seven days the mountain burned, for seven days there was a downpour. The earth split open. Cracks were filled with 
water. For seven days they filled up, and hail fell. For seven days snow fell. Then it was cold. Only seven brothers knew fact that there would be a flood. They were pure people. The eldest brother was called Erlik, and younger was called Ulgen, [he had] come from the gods, a scribe. The brothers built an ark. This ark all was everything that exists on Earth, - birds, insects, animals - they took one pair with them. Ulgen, to check whether the flood was over, released the chicken from the ark.]

2 Така дезе, соокка тогып калган. Ан сонда касты божоттыр. Кас дезе сугле ыгып, ойдо ньанмынсан. Ӱчӥнче катап Ӱлген кускунды ийдир. Кускун база ойдо келбеен, ӧлӱмнин эдини очип чӱрдир. Ӱгреде четти шын карындаш керебтен шыкпартырлар. Ӱлген дезе кижи чайап эттир. Ол дезе, кӧк чакайакты алалып, алтын айакка салалып, кижи чайап ийдир. Улуг кардашы, эрлик, аны артык кӧрип, чарым чакайаны оорлап алтыр, Ӱлген шылап, кижи чайап ийдир. Ага каны курган Ӱлген шогырсалтыр ан чайан кижизини, пийде айдып: - Кара каш курлу кара калык болзын, сеен чайан албатын! Меен ньоным кӱн шыгар ньанса, барсын, сен кара албатын кӱн падыш ньанса барзын!

[The chicken froze in the cold. After this [Ulgen] released a goose. The goose, after it swam away on the water, did not return. The third time Ulgen sent a raven. The raven also did not come back, it flew off to hunt. Then the seven righteous brothers left the ark [onto dry land]. Ulgen made a human. Then he took a blue flower, put it in a golden cup, and made a human. The elder brother, Erlik, envious, robbed him of half a flower and, like Ulgen, created a human. Enraged at him, Ulgen cursed the human he had created, saying, 'Black people with black leather belts will be the people you have created! May my people go toward the rising sun, while your black people go in the direction of the sunset!']

3 Пир катап эрлик ньаа ӧргӧӧ кӧрип алтыр. Очаан келеле, кӧрзе - ан ичинде чылач кижилер чатчын. Ӱлген дезе пу Эрлик чугы-чугы этпезин деп, эгерди эжик алдында артыссалтыр, 


\section{Biblical Legends in the Folklore of the Turkic Peoples 139 in Southern Siberia}

Эрликти божатпа деп, эрлик дезе эгерди айлындырып, айттыр: - Шпа деп, мен саа чылыг некей берин, сокка тограссын. Аш берем, аны чийип алзан, пир ай аштабасын. Эгер дезе аг ӱрбегине пӱткел, эрликти ӧргӧн ичинса пожот ийдир. эрлик киреле, айдыр: «Пу мынар пеес мен калыгым полор» - деп айдала, бойынын кудыны чатчын кижилере ӱбӱре пертир. Кижилер тирилпанар, уйгудан турган шылап.

[Once Erlik saw the new palace. He approached it and looks in, there are naked people inside. So that Erlik could not do interfere in any way, Ulgen had placed a dog at the door, ordering him not to allow Erlik in. Erlik, who drove the dog into a frenzy, said: 'Wait, I'll give you a warm coat in the cold so you do not freeze. I will give you food, if you eat it, you will be full for a month.' The dog believed him and let Erlik into the palace. When he entered, Erlik said, 'These birds will be my people.' Having said this, he breathed his soul-kut in the people lying there. People came to life as if awakened from sleep.]

Kovcheg [Ark]. Published: Oinotkinova, et. al. 2011, p. 126-131. Rec. by K.E. Ukachina in 1974, at vill. Bol'shoy Yaloman of Ongudai district of Republic Altai from A.T. Agadina, 78 years old, a tribe Maiman. Trans. I.B. Shinzhin, E.E. Yamaeva, N.R. Oynotkinova.

4 Бу чӧрчӧк озодо јаан чайык болгоныла колбулу. Алтайда, кандый да бир кобыда, бала-баркалу эмеген-ӧбӧгӧн јуртаптыр. Ӧгӧни иштенкей де, санаалу-укаалу да, нени ле эдип билер кижи болгон. Ол кижи јуртап јаткан эжине бир де неме айтпай, јӱре ле берип турар. Ол тужында ӱй кижи эр кижинен: «Кайда болдын? Неге бар јадын?» - деп, сурак бербейтен. Ондый јан болгон. Онойып, ол кӱнӱн ле јӱре бер турар, энирде арыган, јобогон, суузаган келер. Эмегени ӱн де чыгарбай, кара суунан уруп ла берер. Байагы кижинин арыганы јоголо берер. Онойып узак ӧйлӧр ӧткӧн. эмегени кара суула азырап ла койор, чылаган кижинин арыганы-јобогоны јылыйып калат. 
[This fairy tale is connected with a great flood that was earlier. In the Altai in some valley a husband and wife lived with their children. Her husband was also a hard-working and wise, he knew how to do everything. This man left, saying nothing his wife, with whom he lived. At that time a woman didn't ask a man, 'Where have you been? Where do you go?' Such was the custom. So every day he goes somewhere and comes back tired, worn out, and hungry in the evening. His wife, without saying a word, just poured out some black water for him. And this person's tiredness disappeared. It continued this way for a long time. The wife shall give [her husband] black water, and his tiredness, fatigue fades away.]

5 Бир кӱн ӱй кижи айлында јаныскан отурарда, јер алдынан курумжы тонду бир кижи келген. Кир келген кижини эмеген алтай јанду кӱндӱлеген. Нени берген дезе? Байагы кир келген кижиге кара суунан уруп берди. Айылчы кижи ичеле, айткан: - Бу кандый тату, јакшы аш! Кижинин арыганынчылаганын јоголтор!

- Сӱттен тамган суу эмей - деди. Энир кирип, кӱн ажарда, айыл ээзи эр кижи база ла терлеген, кара сууга аккан, арыганјобогон јанып келди. Эпши кижи байагы ла јылымзу ажыла азыраган. Арыган кижи ӱч айак јылымзу курсактан ичип, кижи эзирерде, эмеген сураган: - Јаан улустын јаныла, эмеген кижи айылдын ээзи нени эдип турганын сурабайтан, је андый да болзо, сурайын деген кӱӱним бар. Сен кӱнӱн ле кайда болуп турган? Энирде арыганчылаган јандын? Кару эжине айтпаста, кемге айдарын?

[Once, when a woman was sitting in an ail (yurt), a man in a felt coat appeared out of the ground. According to Altai custom woman offered him hospitality. What did she give him? She poured a black water for the man. The guest drunk it and said 'What a delicious, good drink! It removes a man's fatigue!' 'It's water obtained from milk,' she said. When evening came, the sun went down, and the man who owned the ail returned all sweaty, covered in black sweat then, tired and warn out. The homemaker gave him the same warm 


\section{Biblical Legends in the Folklore of the Turkic Peoples 141 in Southern Siberia}

drink to drink. When the tired man had drunk three cups of the warm drink and got drunk, his wife asked, 'According to custom of the elders, a woman should not ask the master what he was doing, but still I want to ask about this. Where did you go every day? [Why] do you come back in the evening tired and worn out? If you don't tell your dear wife, then whom can you tell?']

6 Айылдын ээзи эр кижи калап калган, тили јымжап, айтты: - Мен - эр кижи, кандый да болзо, сескир болор учурлу. Сен неме сеспей турун ба? Удабас ла јаан чайык чыгатан эмтир, јер эмештен кыймыктап турганын билбей турун ба? Менин эдип-јазап турган неме јажытту эмей. Оны не јарлаар? Бӱгӱн эдетен, јазайтан немени бӱдӱрдим. эмди коркыыр-ӱркӱр неме де јок. Ол кӱннен ала бйгӱнги кӱнге јетире капчык (сал) јазап турган эдим. Бала-баркамды, сени, бойымды аргадаар керек. Ӧскӧ до ӧзӧктин улузы капчык јазап турган болор. Кажы ла тынду неме тынын аларга турган болбой. Эмеген-ӧбӧгӧннин мынайып эрмектежип, куучындажып турганын байагы сары курумжы кийимду, јер алдынан чыккан кижи јажынала, угуп јаткан. Јадала сананган: «Акыр, бу улуска эмеш каршуум јетиретем». Тӱнде барала, капчыктын тӱбин ойып койгон, суу киреле, бу улус чӧнип калзын деп. Айылдын ээзи билеле, капчыктын тӱбин ойто јазап койгон.

[Drink had loosened the master of the house, the man's tongue, and he said, 'I am a man, and no matter what, I have to be cautious. Do you sense nothing? Soon there will be a big flood, it turns out, do not you feel that the earth is shaking a bit? What I do, it's secret after all. Why announce it? Today, what I did, I was building, I finished. Now we will not be afraid of anything. From that day until today I built an ark (raft). I need to save my children, my heirs, you, and myself. In other valleys people are probably also building arks. Every living being, of course, wants to save its life.' She told what her husband had said to the man in the yellow felt clothes that had appeared out of the ground, who had been hiding, and eavesdropping. Laying down he thought, 'Let me do a little harm these people.' At night he goes out there, he had drilled a hole in the 
bottom of the ark so it would flood, so that these people would drown. The master of the house found out and repaired the bottom of the ark again.]

7 Онойып турганча, суу кӧдӱрилген, чайык башталган. Балдары, бойы, сегис кижи капчыкка отыргылаган, кажы ла агаштын ӱренинен, тобрактан алып, ӧрӧ јӱзерге ле турарда, эмегени качып јӱгӱрген. Јӱгӱрип отырган эмегенди кайыгыла кийнинен ары ӧрӧ кӧдӱреле, капчыкка отургызып алган. Келиннин кийип алган кийими кийининен ырыла берген. Онон ло улам эмди ӱй улустын чегедегинин кийини јырыкту болуп калган. Је ол ло болгон. Олор капчыкка отырып алала, тынын аларга јӱзӱп ле јӱрген. чайык тӧртӧн кӱннин туркунына болгон. Тӧртӧн кӱннин туркунына суу кӧдӱрилген. Ол јемирилип, талтабыш коркышту ла болгон, кӱзӱрт эмес кӱзӱрт турган.

[Meanwhile, the water rose, the flood began. The children, he himself, eight people had boarded the ark, taking along seeds from every tree, some earth, and as soon as they started to go up [river], the wife began to run away. [The husband] picked up the paddle and pulled his runaway wife back onto the ark., The clothes she was wearing got torn in the back. That's why, since that day, a woman's chegedek [robe] back has a cut in the. And so it was. All those who boarded the ark to save themselves kept on sailing. The flood continued for forty days. For forty days the water rose. Everything was destroyed, there was a terrible noise, like thunder, like it was thundering.]

8 Капчыкта отырып алган улус суу ӱстинде кайкалап јӱрген тындууны јууктада тартып алып, оныла ла ажанган, аргаданган. Онон чайык јабызап, суу тӧмӧндӧгӧн кийнинде, кобылар, јиктер, капчалдар бӱткен. эмдиги таркап барган улус ол ло капчыкла аргаданган балдардан таркап барган. Агаш олордын кажы ла агаштан алган ӱреннен ӧзӥп јаранган, Алтайды бӱркеген. Ол эр кижи балдарынын балдарына ат адаган. Балдарынын ады малдын кажы ла ӱйе-сӧӧгиле адашташ. чандыр јигени - чапты, картазын јигени - Кыпчак. 


\section{Biblical Legends in the Folklore of the Turkic Peoples 143 in Southern Siberia}

Онон арыгызын ундып койгон.

[The people on the ark caught nearby animals floating on the water and ate them, so they survived. Then, after the flood began to break, the water began to decline, gorges, meadows, and valleys appeared. Then children were born to the people who had survived on the ark. Trees have grown from those seeds taken from each tree, that have covered all of Altai. That man named his children's children. The children were given names according to the body parts of animals. One who ate tripe, [named] Chapty, one who ate fat - Kipchak. What happened next I have forgotten.]

Shaiyk [The Flood]. Published: [Arbachakova 2010, c. 328-333].

Rec. L.N. Arbachakova in 2000 in the village Usinsk

Mezhdurechenskiy district of L.N. Akushakova.

9 Пир эр кижи қатынма ийгеле пала чоқ чаттырлар. Эртен тура ла, қатынға пирда небе айтпан, ээде ле малта алыбал, парыбысчаттыр. Анаң иирде маттар кӱжӱ шықпар, келчитқан полтур. Кӱн-сайа ээде иштеп, чӧрчаттыр. Қаты ааң сурағанда, пирда небе айтпанчаттыр.

— Қачен иштебиссем, анаң айдарым! — теп.

[One man alone lived with his wife with no children. [The husband] gets up in the morning and always leaves her without saying anything. He took an ax along. He came home very tired. And so every day he goes to work. When the wife asked where he go, he would not say a word to anyone.

— When I'm done, then I'll say!]

10 Анаң пир кӱн эри ишке парыбысқанда, ол қатқа при кижи келтир. Анаң қатын сураптыр:

— Сеең эриң қайа чӧрча, ноо иштепча? — теп.

Қат айттыр:

— Эзе, сурапчам-но, пирда небе айтпанча. 
Азы тезе айттыр:

- Че, сен чақшыба суразаң!

Ааң соонда қаты қадақ сураптыр, азы пирда айтпача. Ол кижи тезе кӱн сайа кел, сураптыр:

- Оңнабалдың ма? - теп.

Кат айтча:

- Пирда айтпанча, теп.

Анаң ол кижи айттыр:

— Ээде полғанда, сен эриңе араға иштепперзең.

Ол темде айна ол позу, кижи полчӧрчитқан полтур. Анан по қат айттыр:

— Қайча араға иштерге, мен пирда оңнабанчам.

Айна айттыр:

- Мен саға айдаперем қайде иштерге: Поза урсал, - теп, айттыр. - Поза турсалзаң, ӱш-тӧрт кӱн турған сооның анаң тигибаларзың, - теп айттыр. - Қайча тикчениң мен полужарым, — теп айттыр.

[One day, when her husband left for work, a man came to his wife, then he asked the woman, 'Where does your husband go, what is he doing?'

The woman said, 'Hey, I ask him, he doesn't not say anything.' And the man says, 'Hey, ask about it in a better way!'

After that, his wife asked again, he did not say anything. And the same person comes each day and asks, 'Did you learn anything?

She replied:

- He does not say anything.

Then the man said:

- If so, make your husband some araga.

At that time Aina [the devil] was in human form. Then the woman said:

- I don't know how to make araga.

Aina said:

— I'll tell you how to do it. You put on a dish, — he said. And after three or four days, distill the araga," he said. "I will help you to distill the araga," so he said.] 
Biblical Legends in the Folklore of the Turkic Peoples 145 in Southern Siberia

11 Анаң ̈ш-тӧрт кӱн сооба, по айнаба қат араға тигибалтырлар. Арағаға тигибалғанда, айна айттыр:

- Ам эриң келип, кӱжӱ шықпарза, орта стакан урубал, - теп, айттыр. Эриң сурар “ноо небе, қайдаң алған?” - теп, сен айдарзың: «Сен кайда айтпан чӧрчазың, мен сага ээдоқ айтпан чӧрерим", - теп.

Анан айна позу чашынпарып уқчаттыр, эр эзирпарза, ноо айтқанын. Ам қатын эри келген ле, по кӱжӱ шықпар келтир. Анаң қаты аға орта стакан араға урпертир, анаң чииш чиирге одурғанда. Эри сураптыр:

— По ноо небе? - теп.

Қаты айттыр:

— Че ишсең, сага чақша полпарар!

Че қаты най кичепчинде, позу ижибистир, анаң айттыр:

- Қайдыг қазыр, ачығ небе теп, по ноо небе иштим? - теп, қатын сураптыр.

Қаты айттыр:

— Че ишсең, саға чақша полпарар!

[Then after three or four days Aina and woman had distilled araga. Once they had distilled the araga, Aina said:

- Now when your husband arriveds tired after work, you pour him half a glass [of araga]. When your husband asks: "Noo, what's that, where did you get it," you say, "Just as you say nothing, I will not tell you anything either."

Then Aina hid to overhear what her husband would say when he was drunk. Her husband came back very tired. When he sat down to eat, his wife poured him (half a cup) of araga. Her husband asked her:

- What is that?

My wife said:

— Well, have a drink, you'll feel good!]

12 Че қаты най кичепчинде, позу ижибистир, анаң айттыр:

- Қайдыг қазыр, ачығ небе теп, по ноо небе иштим? - теп қатын сураптыр.

FOLKLORICA 2016, Vol. XX 
Қаты айттыр:

- Сен қайда маға айтпан чӧрчаңноо иштепчитқанын, мен саға эдоқ айтпассым.

Че, анаң чӱче одуруп, айттыр:

- Пар полза, еще перзең, чақша полпарды.

Анаң қаты еще урпертир. Анаң пазок ижибискенде, ага чақша полпартыр. Анаң айттыр:

- Все равно ам сага айтпассым, ам кӧп тем қалбады ол ижимни иштебизерге. Қачан иштебиссем, анаң пирге парарыбыс кӧрерге.

[When my wife insisted that her husband drink, he says:

- What a strong, bitter drink, what did I drink? - He asked his wife.

His wife said:

— Just as you go and say nothing to me, I won't tell you anything. Well, after sitting a little bit, [the husband] says:

- I feel good, if there is more, give me some (more).

Then my wife poured (some more). When he had drank it up again, he felt good, he said:

- I (still) won't tell you. Now there's not much time left. I'll do my job, then we'll go together to see.]

13 Анаң по чат узупертир. Эртен қатты турғанче, уже эри парыбыстыр. По айна қадақ келтир:

— Чоқ чақкша сурабадың? - теп сураптыр. - Эзирпарған да, сурар кереқ-но.

Анаң по айна қатқа айттыр:

- Пӱӱн келзе, пазоқ араға урперзең, канче ла сураза, ӧжен урпер.

Анаң ийги кӱн ээде полтур. Анаң ӱжӱнче кӥнӱнде эри айтпертир.

— Ам пир кӱн қалды, кӧпчег (сал) иштепчам! — теп.

Қаты айттыр:

— Ол ноо небези? - теп. 


\section{Biblical Legends in the Folklore of the Turkic Peoples 147 in Southern Siberia}

[Then he lay down to sleep. In the morning, before the wife got up, the husband had (already) left. Again Aina appeared:

- Why didn't you not ask him again? - So he said. - You had to ask again while he was drunk.

This Aina said to the woman:

- Today, when he comes, you serve it again, no matter how much he asks for, pour him that much.

This was repeated for two days. On the third day her husband says: — Now only one day remains - (the ark), the raft will be ready! The wife said:

— What's that?]

14 Айна тезе чашынпар уқчаттыр. Ол қатты сурағанда, эри айттыр:

- Ол эңне мӧзӥк тағында сал иштепчам.

Анаң сураганда:

- Ол салды нӧрек иштепчаң? - тенде.

Ааң эри айттыр:

- Ам вот-вот қалбада, по чер чарықта эбире наводнение полар, - тедир. - Ноо, ол салға по чер чарықта қанче ла пар аң-қуш параба ол салада полар, анаң пир эр, пир қат. Ол наводнение сооның қалган аң-қуш, қалған кижи чайалар!

Че, по айна уғубалтыр, қайдығ черге иштепчитқанын. Анаң қараазыба ол кӧпчекты тилеп партыр. Анаң тилеп пар, табалып, эбире чӧр кӧртир, анаң санапчаттыр по ноо иштебизерге. По ааң-қушпа киже қалбазын, по черге чӧр санабал. Анаң пурба албалып, тешик кӧпчеққе пурубустыр, чтобы суғ кирзын теп.

[At this time, Aina was eavesdropping, in hiding. When the woman asked this, her husband said:

- On the highest mountain I'm building an ark.

When she asked:

— Why are you building an ark?

The husband said:

— Now (just about) (the flood) will soon be all over the earth — he said. - In this ark from all over the earth will gather all the living 
beings, as many animals, birds as there all - all in pairs, then one man and women. After (the flood), which drown everything, all will be reborn from the surviving birds, animals and people!

Aina overheard everything, where, in what place he was building the ark. At night he went to look for the ark. After he had gone, he began to walk, to think about how to make all people and creature die. There would be no birds, no animals, no people left on the earth! Then he took a drill and made a hole in the ark, so that water could get in [in the ark].]

\section{5 Че, анаң по эртен эри айттыр:}

— Че, ам параң, эмге паза келбеспис, кӧпчекте қаларыбыс.

Че, анаң салға кирзелер, парчын аң-қушты пир парадың салдылар. Анаң салга кирдилероқ, сал кӧдӱрӱлибистир, весь по черде суғ ӧре кӧдӱрӱлӱбискен. Анаң ээде ле салда ал чӧрчаттыр. Анаң по эр кӧрзе, по салда суғ кирчаттыр. Анаң ноо поңма иштерге. Че, анаң ээде тилепчитқанда, кӧшкечек келкел, кузуруғын тешиқке суқсалтыр. Анаң суг кирбенсалтыр. По кижилербе аң-қуш тириг қалтырлар.

Анаң сал шаптырпартыр эңне мӧзӥк таға Арарат теп, таға. Анаң аң-ауштар по черге қадақ чайалғаннар.

[Then in the morning her husband says:

- Well, now let's go, we will not return home again — we will remain (on the ark).

But when they came to the ark, then they let on all sorts of birds, animals (in pairs). Then they got on [the ark], the raft rose up right away in the water, everything around them flooded. Right away the raft was weaving back and forth. Then a man sees that water was coming into the ark. He began to think about how to close the hole. But while he was thinking, (a little cat) came, stuck its tail in the hole. Then the water could not get in. All people, animals, birds survived.

Then the ark washed up on the highest mountain Ararat, Ararat mountain. Then, on this earth, the beasts and birds began multiply again. ] 